\title{
Studies on the Effect of Micronutrients on the Yield, Quality of Mango Varieties under UHDP (Ultra High Density Planting)
}

\author{
T. Senthivel and M. Kaleeswaran* \\ Department of Agriculture and Animal Sciences, Gandhigram Rural Institute-Deemed \\ University, Gandigram-6240302, India \\ *Corresponding author
}

\section{Keywords}

Total soluble

sugars, Reducing and non reducing sugars, Vitamin C

Article Info

Accepted:

15 November 2019

Available Online:

10 December 2019

\section{A B S T R A C T}

Field experiments were conducted during the year 2013 and 2014 under ultra high density planting mango at research and development farm of Jain Irrigation Systems Limited, Udumalpet with four years of mango varieties viz., Alphonso, Himampasand, and Banganapalli trees were selected for the study. The spacing of the grafts was $3 \mathrm{~m} \times 2 \mathrm{~m}$ with a plot size of $4 \times 8 \mathrm{~m}^{2}$ comprising a population of 1667 plant / hac. The experiment was laid out in split plot design with three mango varieties in the main plot and micronutrients in sub plot treated with seven treatments. Three treatments were treated as foliar application and three treatments were applied as soil application through drip system and remaining one treatment was treated as control. The result on the highest tree height in Banganapalli, stem girth in (V2) Himampasand and canopy spread in Banganapalli (V3). Among the treatments, soil application of $0.1 \%$ boric acid through drip significantly performed better than the other treatment in both the year of experimentation. Banganapalli (V3) recorded the highest chlorophyll content, soluble protein content and total phenol content; whereas Himampasand recorded the highest activity of nitrate reductase and IAA oxidase. Banganapalli performed better than the other varieties in respect of yield and other important yield components in both 2013 and 2014. 0.1 percent Boric Acid (M2) registered significantly higher number of panicle per tree, panicle length, fruit set (\%), fruit girth, fruit length and fruit volume and also the number of fruits per tree. These yield components ultimately resulted in higher fruit yield than the other varieties and treatments. Himampasand recorded the highest TSS ( $\left.{ }^{\mathrm{O}} \mathrm{Brix}\right)$, total sugars, reducing and non reducing sugars. Alphonso recorded higher ascorbic acid total carotenoid and titrable acidity content than the other varieties. Boron at $0.1 \%$ as boric acid applied through drip fertigation significantly recorded the highest TSS ( $\left.{ }^{\circ} \mathrm{Brix}\right)$, total soluble sugars, reducing and non reducing sugars, vitamin $\mathrm{C}$ and total carotenoid content. Banganapalli recorded the highest nitrogen phosphorus and potassium, boron, zinc and iron content as compared to the other varieties Alphonso grown field recorded highest available nitrogen, phosphorus and potassium content than the other varieties. The soil available micronutrients viz., boron, zinc and iron were found to the high in M2 M4 and M6 respectively. The highest net return and B:C ratio was registered with Banganapalli in M2. 


\section{Introduction}

Mango (Mangifera indica L.) belong to the family Anacardiaceae, is one of the most popular fruit crops in the tropical and subtropical regions of the world. It has been under cultivation in the Indian sub-continent for the past 4000 years (De Candolle, 1904) and is said to have originated in the IndoBurma region (Mukherjee, 1958). It is termed as the "King of the fruits" owing to its captivating flavor, delicious taste and an excellent source of vitamin $\mathrm{A}$ and $\mathrm{C}$.

India continues to be the largest mango producing country of the world, accounting for more than 50 per cent of the world production. Currently, mango is cultivated in an area of 2.5 million hectares with an annual production of 18 million tonnes in India. In Tamil Nadu, it is grown in an area of 0.15 million hectares with a total production of 0.71 million tonnes and 4.7 tonnes $\mathrm{ha}^{-1}$ productivity (NHB, 2013). The productivity in India was only 7.2 tonnes $\mathrm{ha}^{-1}$ which was considerably lower in comparison to other mango producing countries. Highest productivity of mango was observed in Cape Verde Island (45 tonnes ha ${ }^{-1}$ ), followed by Samoa (40 tonnes $\mathrm{ha}^{-1}$ ) and Guatemala (26.75 tonnes $\mathrm{ha}^{-1}$ ) but they are not the large scale mango producing country. However, the productivity was lower in the countries producing mangoes commercially (Prakash and Singh, 2014). Improvement of productivity in mango continues to be the foremost issue in mango production (Sauco, 1993). Of late, all the mango importing countries are considering the India as a source of quality mangoes due to its varietal wealth and availability. Hence, it is imperative to improve the productivity and quality of Indian mangoes to meet the global need (Balamohan et al., 2014). So the reasons are many, small size orchards, low yielding traditional varieties, poor orchard management like existence of wider spacing, poor or nil nutrient and canopy management practices and inadequate technological upgradation are the major constrains for lower productivity of mango orchards. Alternate bearing nature of most of the commercial varieties of India is yet another important factor leading to the lower productivity. Moreover, the lack of high density planting per unit area and information on higher tech fruit culture practices, particularly with crop regulations. It is utmost important to standardize the crop regulation to promote their efficiency of orchards. Mango continues to be one of the choicest fruit crops from the accounts of trade and profit. The rising demand for mango due to population and income growth will increase the pressure for increased and more sustainable production to meet the requirements. The challenges are stiff yet achievable with appropriate technologies and large scale adoption by the growers (Prakash and Singh, 2114). Mango cvs. Alphonso, Banganapalli and Himampasand have a biennial bearing in which this alteration is more pronounced. Though, several researchers have attempted to find out the technologies to overcome the irregular bearing problem of mango, the research on Alphonso and Himampasand is found to be very scanty under UHDP. The research efforts to increase the productivity of these varieties will definitely be a boon to the farmers as this is the most relished fruits by the consumers. This experiment was carried out in the mango cvs. Alphonso, Banganapalli and Himampasand under ultra high density planting. The spacing of the mango trees is $3 \mathrm{~m}$ $\mathrm{x} 2 \mathrm{~m}$, to explore the maximum utilization of land. Of late, the ultra high density planting systems are becoming popular among the farmers. Generally, the micronutrients are applied through foliar spray to correct the micronutrient deficiencies in lower amount in order to improve the fruit quality in mango. Nutrients become quickly available to the plants by the foliar application than the soil 
application (Silberbush, 2002). Various experiments have been conducted earlier on foliar spray of micro-nutrients in different varieties in mango (Nehete et al., 2011). Foliar fertilization has the advantages of low application rates, uniform distribution of fertilizers, quick responses to applied nutrients and so the hidden hungers can be easily managed. In Tamil Nadu the micronutrient deficiencies are identified as one of the key barrier in augmenting productivity of mango crops and the deficiency of micronutrient viz., zinc, boron and iron were observed in the soil of Tamil Nadu. Fertigation is the best solution for optimum use of water as well as fertilizer and leads to intensive and economical crop production as both water and fertilizers are delivered to growing crops through microirrigation systems. Fertigation provides direct placement of essential and required nutrition into the active root zone, thus not only minimizing losses of expensive nutrients, but also improving crop productivity and quality of farm produce. The technique also helps in savings of time and labour.

Experiments have proved that the fertigation helps in saving of fertilizer and water ranging from 40-60 per cent. Fertigation is ideally suited for various hi-tech horticultural crops and agricultural crops grown under Micro Irrigation technologies. Chelates and sulphate compounds of various- micronutrients are generally used for fertigation. These compounds should be pre-dissolved and metered as a liquid. The micronutrients that can be supplied via irrigation system include: copper, iron, zinc, manganese, boron and molybdenum. With this background, this study on "Studies on the effect of micronutrients on yield quality and marketing of mango's varieties under UHDP (Ultra high density planting)" was undertaken at Jain Irrigation System Limited (JISL) Elayamuthur, Udumalpet during the year 2013\&2014 and with the following objectives:
To find out the effect of foliar application of micronutrients on the yield and quality of fruits in mango varieties.

To study the effect and influence of soil application of micronutrients through drip irrigation on the yield quality mango varieties and

To find out the economics and $\mathrm{B}$ : $\mathrm{C}$ ratio of application of micronutrients on mango varieties.

\section{Materials and Methods}

Field experiment was conducted in the Research and Development Farm of Jain irrigation Systems Ltd., located in the Udumalpet Taluk of Tirupur District (TN). The farm is situated in the Western Agro climatic zone of Tamil Nadu at $10^{\circ} 34^{\prime} 48^{\prime \prime} \mathrm{N}$ Latitude and $77^{\circ} 14^{\prime} 24^{\prime \prime}$ E longitude and at an altitude of $340.46 \mathrm{~m}$ above MSL. The soil of the experimental field is sandy loam with good drainage. The available soil nitrogen, phosphorous and potassium were medium status and soil PH 6.9 and EC 0.69.

\section{Experimental design and layout}

The experiment laid out in split plot design with three mango varieties in the main plot and micronutrients in sub plot with a plot size of $4 \times 8 \mathrm{~m}^{2}$.

\section{Results and Discussion}

The results of the experimented data / analyzed under viz., 1. Growth parameters, 2) Physiological attributes, 3) Yield attributes, 4) Nutrient uptake and 5) B: C ratio. The important findings of the experiments and the conclusion drawn out of the investigations are summarized here under. The results on growth components viz., Tree height, stem girth, canopy diameter and canopy spread indicates 
that it was significantly influenced by both varieties and micronutrient treatments. Among the mango varieties, the highest tree height in Banganopalli $\left(\mathrm{V}_{3}\right)$ stem girth in $\left(\mathrm{V}_{2}\right)$ Himampasand and canopy spread in Banganapalli. Among the treatments, $\left(\mathrm{M}_{2}\right)$ soil application of $0.1 \%$ boric acid through drip significantly performed better than the other treatment in both the years of experimentation in ultra high density planting.

The physiological attributes viz., chlorophyll content, total phenol content, soluble protein, nitrate reductase activity, IAA oxidase activity and $\mathrm{C}: \mathrm{N}$ ratio were studied in the present investigation and found that Banganapalli (V3) recorded the highest chlorophyll content, soluble protein content and total phenol content; whereas Himampasand recorded the highest activity of nitrate reductase and IAA oxidase. Among the treatments, $\mathrm{M}_{2}$ recorded total chlorophyll, phenol content and soluble protein content. $\mathrm{M}_{6}$ recorded the highest activity of nitrate reductase and IAA oxidase. The results of the yield and yield attributes were significantly influenced by the varieties and treatments. Among the varieties, Banganapalli performed better than the other varieties in respect of yield and other important yield components in both 2013 and 2014 under ultra high density plant. $\mathbf{M}_{2}$ registered significantly higher number of panicle per tree, panicle length, fruit set (\%), fruit girth, fruit length, fruit volume and also the number of fruits per tree. These yield components ultimately resulted in higher fruit yield than the other varieties and treatments. With respect to quality attributes, comparing the varieties, it was revealed that Himmampasand recorded the highest TSS $\left({ }^{\circ}\right.$ Brix), total sugars, reducing and non reducing sugars. Alphonso recorded higher ascorbic acid total carotenoid and titrable acidity content than the other varieties.

Among the treatments, boron at $0.1 \%$ as poric acid applied through drip fertigation significantly recorded the highest TSS ( ${ }^{\circ} \mathrm{Brix}$ ), total soluble sugars, reducing and non reducing sugars, vitamin $\mathrm{C}$ and total carotenoid content. In the case of nutrient content in leaves at flowering stage, Banganapalli recorded the highest nitrogen, phosphorus and potassium, born, zinc and iron content as compared to the other varieties $\mathbf{M}_{2}$, $\mathrm{M}_{4}$ and $\mathrm{M}_{6}$ significantly recorded the highest boron, zinc and iron content respectively. The post harvest soil analysis recorded that the soil from the Alphonso grown field recorded highest available nitrogen, phosphorus and potassium content than the other varieties. The soil available micronutrients viz., boron, zinc and iron were from to the high in $\mathrm{M}_{2} \mathrm{M}_{4}$ and $\mathrm{M}_{6}$ respectively. The highest net return and $\mathrm{B}: \mathrm{C}$ ratio was registered with Banganapalli in $\mathrm{M}_{2}$ (Table 1-4).

\section{Table.1}

\begin{tabular}{|c|c|c|c|}
\hline \multicolumn{2}{|c|}{ Treatment details } & & \\
\hline & Main plot & $:$ & Mango varieties (3) \\
\hline 1. & Alponso & $:$ & $\mathrm{V}_{1}$ \\
\hline 2. & Himampasand & $:$ & $\mathrm{V}_{2}$ \\
\hline 3. & Banganapalli & $:$ & $\mathrm{V}_{3}$ \\
\hline
\end{tabular}


Table.2

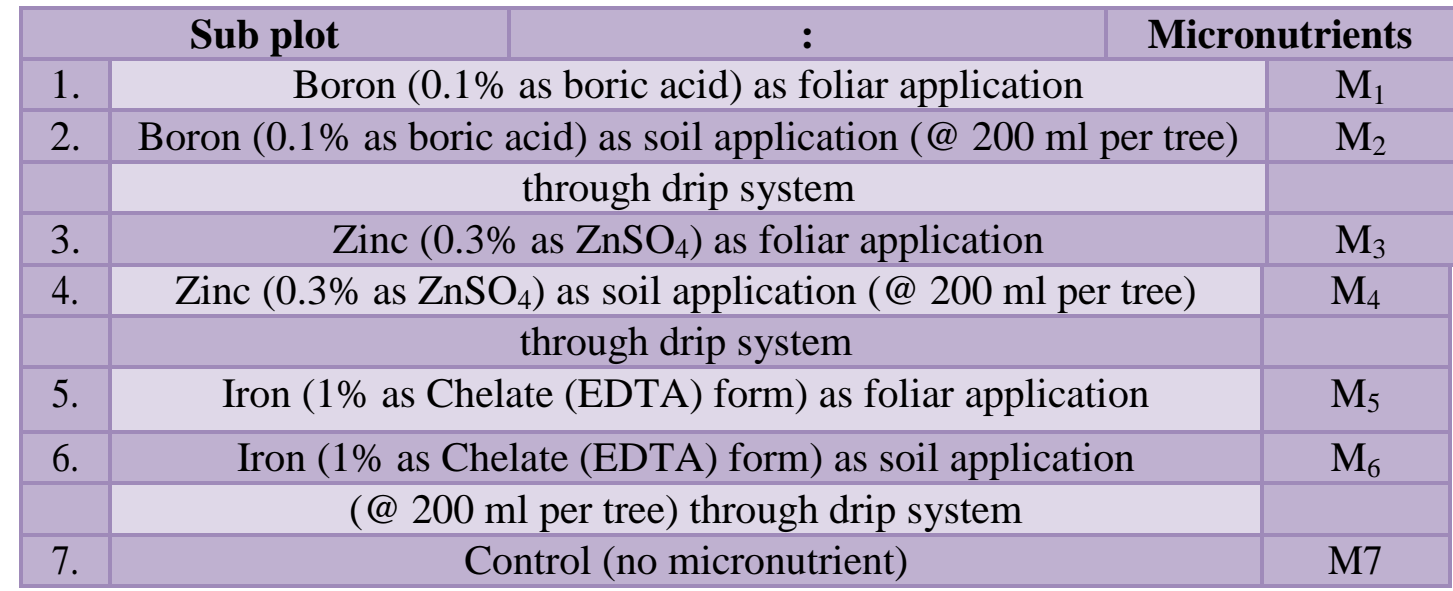

Table.3 Effect of micro nutrients on yield per tree in mango varieties

\begin{tabular}{|c|c|c|c|c|c|c|c|c|}
\hline \multirow{2}{*}{ Treatments } & \multicolumn{3}{|c|}{2013} & \multirow{2}{*}{ Mean } & \multicolumn{3}{|c|}{2014} & \multirow{2}{*}{ Mean } \\
\hline & $v_{1}$ & $\mathbf{V}_{2}$ & $\mathbf{V}_{3}$ & & $v_{1}$ & $\mathbf{V}_{2}$ & $V_{3}$ & \\
\hline$M_{1}$ & 9.240 & 7.350 & 10.000 & 8.863 & 12.084 & 10.200 & 12.090 & 11.458 \\
\hline $\mathbf{M}_{-2}$ & 11.084 & 11.000 & 11.368 & 11.151 & 16.368 & 16.100 & 18.020 & 16.829 \\
\hline $\mathbf{M}_{3}$ & 9.610 & 9.500 & 10.100 & 9.737 & 13.609 & 12.480 & 13.398 & 13.162 \\
\hline $\mathbf{M}_{4}$ & 10.272 & 9.054 & 10.478 & 9.935 & 15.356 & 14.910 & 15.600 & 15.289 \\
\hline$M_{5}$ & 9.920 & 9.373 & 10.080 & 9.791 & 11.914 & 10.184 & 12.040 & 11.379 \\
\hline $\mathbf{M}_{6}$ & 10.779 & 10.466 & 10.920 & 10.722 & 14.291 & 14.300 & 16.320 & 14.970 \\
\hline $\mathbf{M}_{7}$ & 6.516 & 5.160 & 6.866 & 6.181 & 8.424 & 7.845 & 8.580 & 8.283 \\
\hline \multirow[t]{2}{*}{ Mean } & 9.632 & 8.843 & 9.973 & 9.483 & 13.149 & 12.288 & 13.721 & 13.053 \\
\hline & SEd & \multicolumn{3}{|c|}{$C D(p=0.05)$} & & SEd & \multicolumn{2}{|c|}{$C D(p=0.05)$} \\
\hline v & 0.044 & \multicolumn{3}{|c|}{0.091} & v & 0.054 & \multicolumn{2}{|c|}{0.110} \\
\hline $\mathbf{M}$ & 0.266 & \multicolumn{3}{|c|}{0.580} & $\mathbf{M}$ & 0.476 & \multicolumn{2}{|c|}{1.038} \\
\hline MXV & 0.283 & \multicolumn{3}{|c|}{0.612} & MXV & 0.490 & \multicolumn{2}{|c|}{1.065} \\
\hline
\end{tabular}


Table.4 Effect of micro nutrients on TSS ${ }^{\circ}$ Brix in mango varieties

\begin{tabular}{|c|c|c|c|c|c|c|c|c|}
\hline \multirow{2}{*}{ Treatments } & \multicolumn{3}{|c|}{2013} & \multirow{2}{*}{ Mean } & \multicolumn{3}{|c|}{2014} & \multirow{2}{*}{ Mean } \\
\hline & $V_{1}$ & $V_{2}$ & $V_{3}$ & & $V_{1}$ & $V_{2}$ & $\mathbf{V}_{3}$ & \\
\hline$M_{1}$ & 17.60 & 21.70 & 20.90 & 20.07 & 18.00 & 21.80 & 20.15 & 19.98 \\
\hline$M_{-2}$ & 18.00 & 21.82 & 20.15 & 19.99 & 18.15 & 21.82 & 20.21 & 20.06 \\
\hline $\mathbf{M}_{3}$ & 17.80 & 19.81 & 19.52 & 19.04 & 17.95 & 19.95 & 19.78 & 19.23 \\
\hline $\mathbf{M}_{4}$ & 17.95 & 21.74 & 20.10 & 19.93 & 18.00 & 20.96 & 20.01 & 19.66 \\
\hline$M_{5}$ & 17.65 & 19.72 & 19.86 & 19.08 & 17.80 & 19.76 & 19.65 & 19.07 \\
\hline$M_{6}$ & 17.95 & 21.76 & 20.12 & 19.94 & 18.12 & 21.46 & 20.18 & 19.92 \\
\hline$M_{7}$ & 17.10 & 19.50 & 19.50 & 18.70 & 16.70 & 18.25 & 19.15 & 18.03 \\
\hline \multirow[t]{2}{*}{ Mean } & 17.72 & 20.86 & 20.02 & 19.54 & 17.82 & 20.57 & 19.88 & 19.42 \\
\hline & SEd & \multicolumn{3}{|c|}{$C D(p=0.05)$} & & SEd & \multicolumn{2}{|c|}{$C D(p=0.05)$} \\
\hline v & 0.105 & \multicolumn{3}{|c|}{0.215} & v & 0.044 & \multicolumn{2}{|c|}{0.089} \\
\hline $\mathbf{M}$ & 0.093 & \multicolumn{3}{|c|}{0.203} & $\mathbf{M}$ & 0.067 & \multicolumn{2}{|c|}{0.137} \\
\hline$M X V$ & 0.245 & \multicolumn{3}{|c|}{0.507} & $M X V$ & 0.117 & \multicolumn{2}{|c|}{0.237} \\
\hline
\end{tabular}

It was concluded from the present investigation that the among the mango varieties tested, Banganapalli was found to be best variety for ultra high density planting as it recorded significantly higher fruit yield than the Alphonso and Himampasand. The soil application of $0.1 \%$ Boric acid (M2) through drip recorded significantly highest yield as compared to the other treatments. Banganapalli responded more to the boron application than the other nutrients. Hence, the highest B: C ratio was registered with Banganapalli.

\section{References}

Ahmad, D., M. S. Asghar Parveen and M. A. Ali. 2012. Evaluation of Kinnow mandarin as influenced by pre-harvest management practices. Journal of Agricultural Research 50(3): 381-392.
Anees, M., F. M. J. Tahir Shahzad and N. Mahommon.2011. Ranchi to Micronutrients on the quality of Mango cv. Dashehari. Mycopath, pp. 25-28.

Keram, K. S. 2014. Response of Zinc fertilization to wheat on yield, quality, nutrients uptake and soil fertility grown in a Zinc deficient soil. European Journal of Academic Essays 1(1): 22-26.

Obreza, T.A., M. Zekri, E. A. Hanlon, K. Morgan, A. Schumann, R. Rouse. 2010. Soil and leaf Tissue Testing for Commercial Citrus Production. University of Florida Extension Service SL, pp. 253.04.

Ryugo, K. 1988. Fruit culture: its science and Art. John Willey and Sons, p. 259-231.

Singh, Y. P., J. P. Tiwari and K. K. Misra. 2003. Effect of micronutrients on fruit 
yield and physic-chemical characters of mango cv. Dehehari. Prog. Hart. 35(1): 34-37.

Swietlik, D. 1999. Zinc nutrition in horticultural crops. Horticultural Reviews 23: 109-180. John Wiley \& Sons, Inc., New York.

Swietlik, D and M. Faust. 1984. Foliar nutrition of fruit crops. Horticultural Reviews 6: 287-355.

Panwar, S, S. K. Singh, C. P. Singh and P. K. Singh, 2007. Mango fruit yield and quality improvement through Fertigation along with Mulch. Indian J. Agric. Sci., 77(10) : 610-684.

Thirupathaiah, G. A. M. Shirol, B. B. Rao and J. Srikanth. 2017. Response of soil and foliar application of zinc, Iron and Boron on biophysical parameters and chlorophyll content of sapota. Int. J.
Agric. Sci., 9(9): 3920-3924.

Balakrishnan, K, A. Subbiah, J. Rajangam, P. P. Mahendran and M./ Prakash. 2018. Nutritional disorders in crop plants. Satish serial Publishing House. New Delhi: p. 146.

Shirgure, P. S, Srivastava A. K, Shyam Singh and Singh, S. 2001. Growth, yield and quality of Nagpur mandarin (Citrus reticulate Blanco) and relation to irrigation and fertigation. Indian Journal of Agricultural Sciences 71(8): 547-550.

Raina, J. N. Sharma T and Suman S. 2011. Effect of drip fertigation with different fertilizers on nutrient distribution in soil, leaf nutrient content and yield of Apricot (Prumus armeniaca L.) Journal of Indian Society of Soil Science 59: 268-277.

\section{How to cite this article:}

Senthivel, T. and Kaleeswaran, M. 2019. Studies on the Effect of Micronutrients on the Yield, Quality of Mango Varieties under UHDP (Ultra High Density Planting). Int.J.Curr.Microbiol.App.Sci. 8(12): 2074-2080. doi: https://doi.org/10.20546/ijcmas.2019.812.245 